\title{
Florian Möslein
}

\section{Dispositives Recht}

\author{
Zwecke, Strukturen und Methoden
}

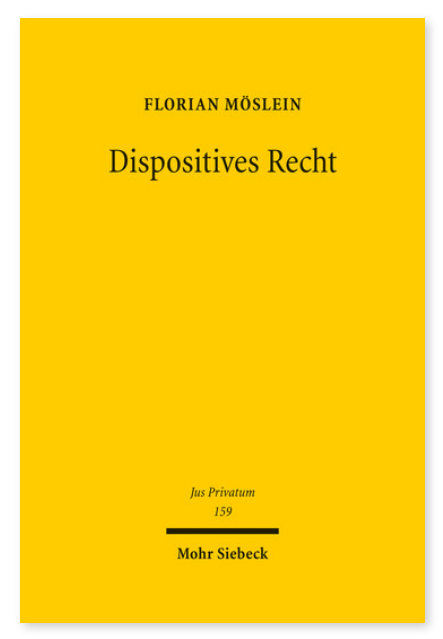

2011. XX, 640 Seiten. JusPriv 159

ISBN 978-3-16-151759-4

DOI 10.1628/978-3-16-151759-4

eBook PDF $144,00 €$

ISBN 978-3-16-150891-2

Leinen $144,00 €$
Dispositives Recht bildet ein allzu unerforschtes Herzstück des geltenden Privatrechts. Statt bestimmtes Verhalten hoheitlich zu erzwingen, eröffnet es Privaten die Möglichkeit, abweichende Vereinbarungen zu treffen. Es beansprucht mithin nur dann Geltung, wenn privatautonom nichts anderes vereinbart ist. Dass die Erzeugung der für privatrechtliche Beziehungen maßgeblichen, rechtlich verbindlichen Regeln auf diese Weise zwischen Staat und Privaten aufgeteilt ist, dass sich dispositives Recht deshalb aus zwei ganz unterschiedlichen Quellen speist, zählt man zu Recht zu den »genialen Eigenschaften« unserer Privatrechtsordnung. Dispositives Recht lässt Privatautonomie und Vertragsfreiheit nicht nur zu, sondern fördert und ermöglicht sie. Die Regelungstechnik bildet deshalb einen tragenden Pfeiler der Privatrechtsgesellschaft, zu deren Markenzeichen nicht hierarchisch-hoheitliche Strukturen, sondern ein hohes Maß an Gleichordnung, private Gestaltungsfreiheit und Selbstverantwortung gehören.

Florian Möslein ist Professor für Bürgerliches Recht, Deutsches und Europäisches Wirtschaftsrecht an der Universität Marburg sowie Gründungsdirektor des Marburger Instituts für das Recht der Digitalisierung (IRDi). https://orcid.org/0000-0002-6733-6102
Jetzt bestellen:

https://mohrsiebeck.com/buch/dispositives-recht-9783161517594?no_cache=1 order@mohrsiebeck.com Telefon: +49 (0)7071-923-17 Telefax: $+49(0) 7071-51104$ 